\title{
PENILAIAN RISIKO TERHADAP POSTUR KERJA PADA PEKERJA PABRIK KARET INDONESIA
}

\author{
Taufiq Ihsan $^{1 *}$, Shinta Silvia ${ }^{1}$, Vioni Derosya ${ }^{2}$, Tivany Edwin ${ }^{1}$, Mita Sari Dewi ${ }^{1}$ \\ ${ }^{1}$ Jurusan Teknik Lingkungan, Fakultas Teknik \\ ${ }^{2} J u r u s a n$ Teknologi Industri Pertanian, Fakultas Teknologi Pertanian \\ Universitas Andalas Kampus Limau Manis, Padang, Indonesia, 25163
}

(Received: May 15, 2020/Accepted: May 20, 2021)

\begin{abstract}
Abstrak
Keluhan nyeri muskuloskeletal sering terjadi di tiga pabrik karet remah terbesar yang berlokasi di Padang, Indonesia. Penelitian ini bertujuan untuk menganalisis postur kerja menggunakan metode Rapid Entire Body Assessment (REBA) untuk pekerja di area produksi. Pengambilan data postur karyawan menggunakan bantuan kamera video serta lembar observasi. Responden dalam penelitian ini terdiri dari 135 pekerja area produksi basah dan 213 pekerja area produksi kering. Penilaian REBA menunjukkan bahwa 72,34\% dari pekerjaan yang diperiksa termasuk dalam kategori risiko menengah. Skor REBA tertinggi di area produksi basah adalah dalam proses pengeringan alami. Sebaliknya, di area produksi kering, skor REBA tertinggi adalah dalam proses mengangkat kontainer dari truk. Berdasarkan Standar Indonesia No.7269 / 2009 tentang perhitungan beban kerja, ini menunjukkan bahwa pekerjaan di pabrik-pabrik tersebut berada dalam kategori beban kerja sedang dengan pengeluaran energi 200-350 kkal/ jam (46,81\%). Hasil uji statistik dari hubungan antara usia, masa kerja, beban kerja, dan area kerja pada pekerjaan postural menunjukkan bahwa beban kerja adalah yang paling terkait dengan postur pekerja. Tindakan untuk memperbaiki postur kerja berdasarkan analisis REBA adalah dengan menyesuaikan posisi alat atau mesin dengan ketinggian tubuh pekerja, memperhatikan waktu kerja, dan waktu istirahat. Yang paling mendesak adalah menggunakan alat saat mengangkat wadah.
\end{abstract}

Kata kunci: Muskuloskeletal, penilaian paparan, postur kerja, REBA, pabrik karet remah

\begin{abstract}
[Risk Assessment of Work Posture In Indonesian Crumb Rubber Factories Workers] Musculoskeletal pain complaints often occur in the three largest crumb rubber factories located in Padang, Indonesia. This study aimed to analyze the work posture using the Rapid Entire Body Assessment (REBA) method for workers in the production area. Retrieval of employee posture data utilizing the help of video cameras and observation sheets. Respondents consisted of 135 wet area workers and 213 dry area workers. The REBA assessment showed that $72.34 \%$ of the work examined was included in the mediumrisk category. The highest REBA score in the wet area was in the natural drying process. In dry areas, the highest REBA score is in the process of lifting containers from trucks. Based on Indonesian Standard No. 7269 /2009, this shows that work in these factories was in the category of moderate workloads with an energy expenditure of 200-350 kcal/hour (46.81\%). Statistical test results from the relationship between age, work-period, workload, and work area on postural work indicated that workload was most related to worker posture. Action to improve postural work was to adjust the position of the tool or machine with the height of the worker's body, pay attention to work time, and rest periods.
\end{abstract}

Keywords: Musculoskeletal, Exposure assessment, work posture, REBA, crumb rubber factories

\section{Pendahuluan}

Secara global, gangguan yang berhubungan dengan pekerjaan (musculoskeletal disorders/ MSDs) adalah salah satu masalah kesehatan terpenting yang

\footnotetext{
*Penulis Korespondensi.

E-mail: taufiqihsan@eng.unand.ac.id
}

dihadapi oleh para ergonomis. Gangguan Muskuloskeletal (MSDs) merupakan penyakit yang paling umum yang terkait dengan kesehatan yang digunakan saat ini. Saat ini, MSDs adalah salah satu gangguan yang paling lazim di seluruh dunia (Chander dan Cavatorta, 2017). MSDs yang terkait dengan pekerjaan mewakili mayoritas patologi pekerjaan dan sering mengakibatkan pembatasan kerja, kehilangan 
waktu kerja, dan hingga berdampak pada pensiun dini (Wahyuniardi dan Reyhanandar, 2018). Gangguan ini juga turut memberikan dampak atas peningkatan kompensasi upah dan biaya pengobatan dan untuk mengurangi produktivitas serta kualitas hidup. Identifikasi risiko postur selama bekerja adalah salah satu bidang penting dalam kajian ergonomi (EneZ dan Nalbantoğlu, 2019). Berdasarkan data dari Departemen Kesehatan Indonesia RI (2019) menyatakan bahwa dalam profil kesehatan di Indonesia tahun 2018, menunjukkan $40,5 \%$ penyakit yang diderita pekerja Indonesia sehubungan dengan pekerjaannya. Data tersebut menunjukkan penyakit MSD's adalah yang tertinggi sebanyak 16\%, urutan berikutnya kardiovaskuler (8\%), gangguan saraf (3\%) dan gangguan Telinga, Hidung dan Tenggorokan (THT) sebanyak $1,5 \%$.

Sebagian besar pekerjaan dilakukan secara manual dengan posisi tertentu, dalam waktu lama, dan postur kerja yang salah sehingga menyebabkan kondisi yang tidak nyaman (Schwartz dkk., 2019). Kondisi kerja ini menimbulkan keluhan MSDs. Keluhan MSDs adalah keluhan yang berada pada bagian otot skeletal atau otot rangka yang dirasakan oleh seseorang mulai dari keluhan sangat ringan hingga sangat sakit. Apabila otot menerima beban statis secara berulang dan dalam jangka waktu cukup lama maka akan dapat menyebabkan keluhan berupa kerusakan pada sendi, ligamen dan tendon. Faktor penyebab terjadinya keluhan muskuloskeletal adalah peregangan otot yang berlebihan, aktivitas berulang, sikap kerja tidak alamiah, penyebab sekunder dan penyebab kombinasi (Wahyuniardi dan Reyhanandar, 2018).

Tempat dan faktor fasilitas kerja manusia mengandung potensi bahaya yang tinggi sehingga diperlukan suatu upaya pencegahan agar tidak terjadi kecelakaan dan penyakit akibat postur kerja yang tidak sesuai. Fasilitas kerja merupakan komponen yang berhubungan langsung dengan manusia dimana rancangan fasilitas kerja yang baik sangat diperlukan sesuai dengan postur tubuh dan beban kerja manusia untuk berinteraksi dengan perlengkapan kerjanya (Arminas, 2017).

Dilihat dari sudut pandang ergonomi, setiap beban kerja yang diterima seseorang harus sesuai dan seimbang terhadap kemampuan fisik maupun psikologis pekerja yang menerima beban kerja tersebut. Beban kerja diartikan sebagai kemampuan tubuh pekerja dalam menerima pekerjaan. Perhitungan beban kerja dilakukan berdasarkan SNI 7269 tahun 2009 tentang Penilaian Beban Kerja berdasarkan Tingkat Kalori menurut Pengeluaran Energi.

Kota Padang mempunyai tiga industri besar pengolahan karet (crumb rubber) dengan kapasitas produksi 96.000 ton/ tahun. Berdasarkan data kecelakaan kerja pada tahun 2019 di tiga perusahaan karet tersebut, terjadi 21 kasus kecelakaan kerja di area produksi. Hampir $30 \%$ dari kasus tersebut terkait
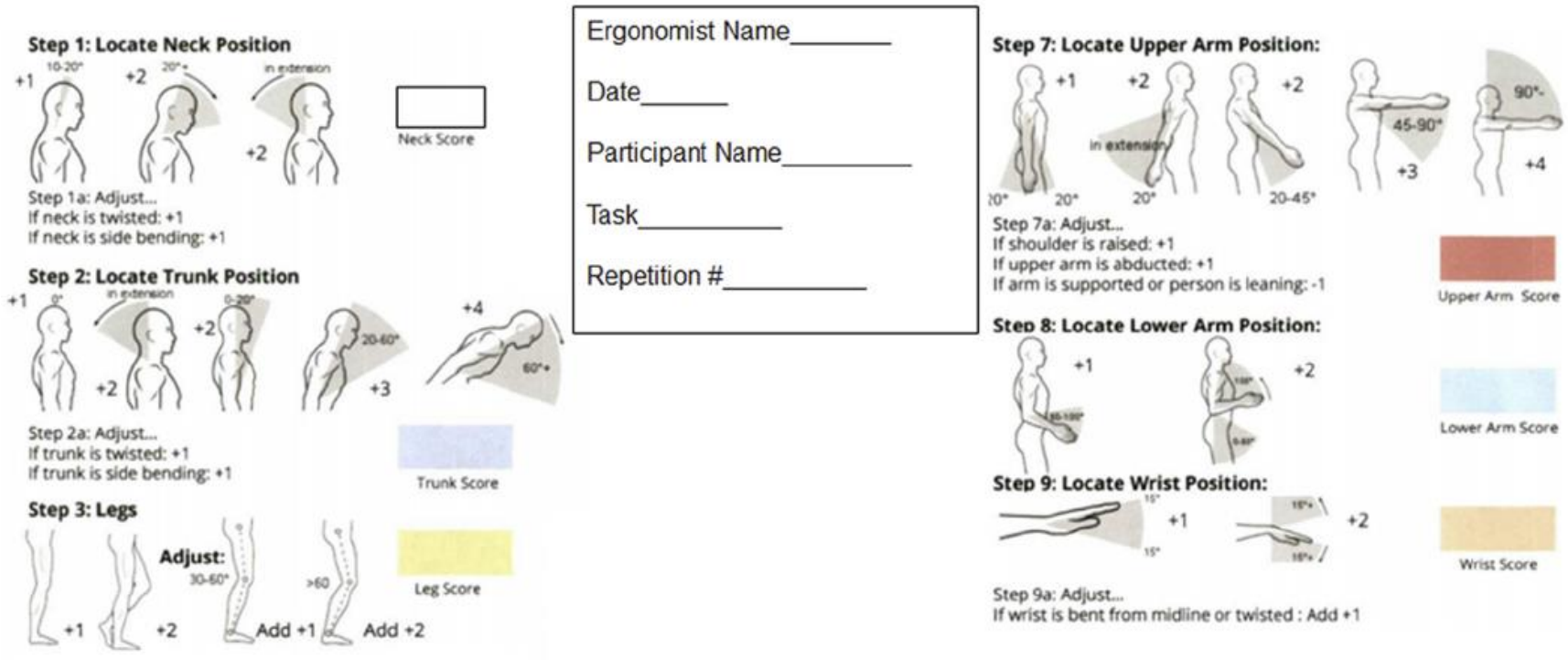

Step 9a: Adjust...

If $\mathrm{wrist}$ is bent from midline or twisted : Add +1

Step 11: Add Coupling Score

Well fitting Handle and mid rang power grip, good: to

Acceptable but not ideal hand hold or coupling

acceptable with another body part, fair: +1

Hand hoid not acceptable but possible, poor: +2

Unacceptable: $* 3$

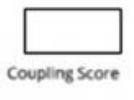

If load 11 to 22 ibs.

if load $>22$ lbs: +2

Adjust: if shock or rapid build up of force: add $* 1$ force / Load score 
dengan gangguan muskuloskeletal tertentu, yang terutama disebabkan oleh terlalu banyak tenaga dan penanganan material yang tidak benar di tempat kerja. Jika para pekerja melakukan pekerjaannya dengan postur kerja yang tidak ergonomis dan tidak memperhatikan faktor-faktor keselamatan kerja pada saat bekerja, maka dapat menurunkan konsentrasi dan tingkat ketelitiannya sehingga dapat menyebabkan kecelakaan kerja di perusahaan tersebut.

Metode yang digunakan pada studi ini adalah metode Rapid Entire Body Assessment (REBA). REBA adalah metode untuk menilai secara cepat postur leher, punggung, lengan atas, lengan bawah, pergelangan tangan dan kaki seorang pekerja. Selain karena menilai risiko pada seluruh bagian tubuh, metode REBA ini telah menjadi metode yang paling sering digunakan dalam industri serta telah diterapkan pada banyak kasus dalam beragam penelitian (Sukadarin dkk.,2016; Kong dkk., 2017; Asadi dkk., 2019; Joshi dan Deshpande, 2019) Penilaian REBA terjadi dalam empat tahap. Tahap pertama adalah pengambilan data postur pekerja dengan menggunakan bantuan kamera video atau foto, tahap kedua adalah penentuan sudut-sudut dari bagian

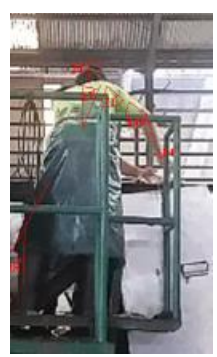

(a)

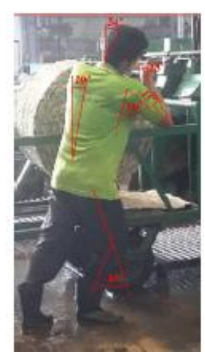

(b)

tubuh pekerja, tahap ketiga adalah penentuan berat benda yang diangkat, penentuan genggaman dan penentuan aktivitas pekerja. Tahap keempat adalah perhitungan nilai REBA untuk postur yang bersangkutan, dengan didapatnya nilai REBA tersebut dapat diketahui level risiko dan kebutuhan akan tindakan yang perlu dilakukan untuk perbaikan kerja (Schwartz dkk., 2019).

Penelitian ini bertujuan untuk 1) melakukan penilaian risiko ergonomis di semua pekerjaan yang dilakukan oleh pekerja di area produksi pabrik karet Kota Padang; dan 2) mengidentifikasi kontribusi beban kerja terkait untuk faktor risiko yang diamati. Hasil penelitian ini memberikan gambaran dan mengevaluasi faktor-faktor yang berkontribusi pada tingginya prevalensi cedera. Selain itu dapat memberikan bahan evaluasi dan pertimbangan bagi perusahaan sejenis untuk menerapkan pengendalian bahaya postur kerja yang tidak ergonomis.

\section{Metode Penelitian}

Lokasi penelitian pada area produksi di tiga industri pengolahan karet di Kota Padang, Provinsi

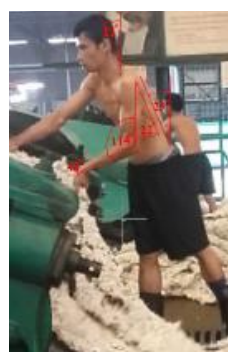

(c)

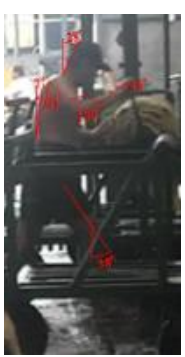

(d)

Gambar 2. Area Produksi Basah (a) Pencucian (b) Pencampuran (c) Penggilingan (d) Pengeringan

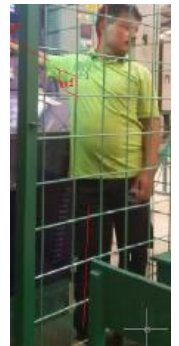

(a)

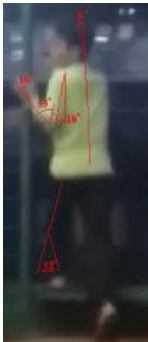

(b)

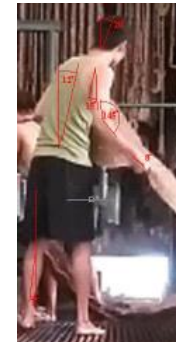

(c)

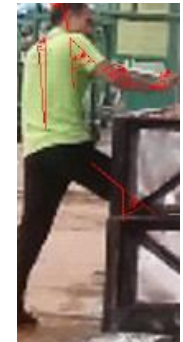

(d)

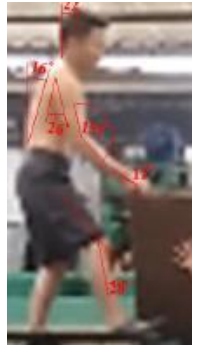

(e)

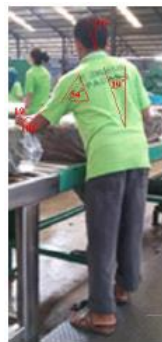

(f)

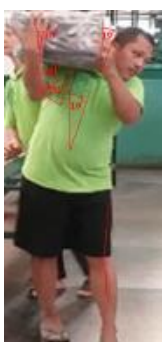

(g)

Gambar 3. Area Produksi Kering (a) Pengawas (b) Asisten Pengawas (c) Pemotongan (d) Pengisian Bandela (e) Penimbangan (f) Pengemasan (g) Pengangkutan

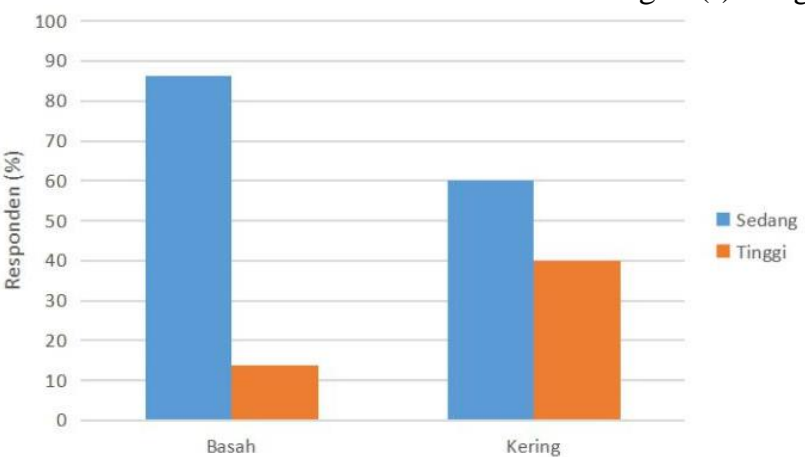

Gambar 4. Persentase Distribusi Beban Kerja

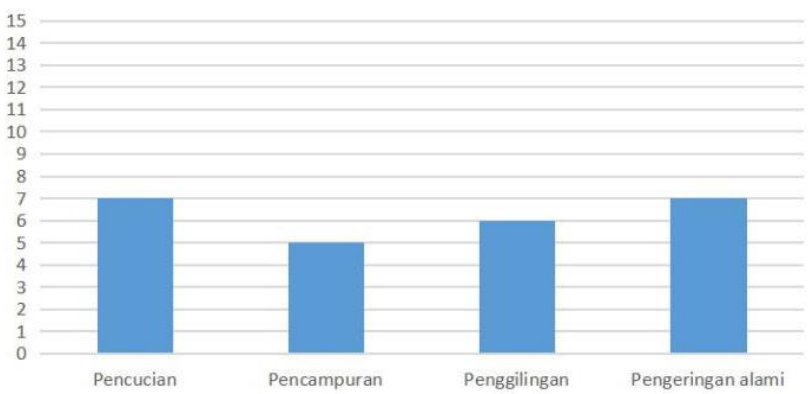

Gambar 5. Skor REBA Rata-rata Pekerja pada Sub Area Produksi Basah 
Sumatra Barat, Indonesia. Tiga Industri ini berada di kawasan industri Kota Padang. Area produksi pada industri pengolahan karet terdiri atas area produksi basah dan area produksi kering.

Pengamatan dilakukan dengan melihat area kerja produksi dan mengamati pekerja untuk melihat postur dan beban kerja. Pengamatan mengacu pada pengisian lembaran observasi REBA berisikan gambar dan penjelasan mengenai tahapan penilaian atau pemberian skor terhadap setiap jenis postur kerja, yaitu skor pada postur leher, punggung, kaki, beban, lengan atas, lengan bawah, pergelangan, genggaman dan aktivitas pengulangan kerja. Jumlah responden dalam penelitian ini adalah 448 pekerja laki-laki yang terdiri dari 135 pekerja area produksi basah dan 315 pekerja area produksi kering. Selanjutnya observasi juga diperkuat dengan mengamati kembali berdasarkan hasil foto dokumentasi amupun rekaman video.

Tahapan pengolahan data meliputi perhitungan skor postur kerja (REBA), perhitungan beban kerja, dan analisis hubungan dan pengaruh antara dua variabel (analisis bivariat). Skor postur kerja dapat diketahui setelah menyelesaikan lembar observasi REBA diperoleh nilai pergerakan tubuh. Hasil lembar pengamatan digunakan untuk menemukan skor REBA di tabel A dan tabel B. Di tabel A ada segmen tubuh dari leher, punggung, kaki, dan bobot). Pada tabel B, ada segmen tubuh lengan atas, lengan bawah, dan pergelangan tangan15. Semua postur kerja pekerja studi selama pemrosesan di area produksi direkam atau mengambil foto dan kemudian dievaluasi menggunakan perangkat lunak ErgoFellow pada Gambar 1. Hasil yang diperoleh dalam tabel skor REBA dapat diketahui tingkat risiko yang terjadi dan perlunya tindakan yang dilakukan untuk perbaikan (Schwartz dkk., 2019).

Langkah selanjutnya dari penelitian ini adalah untuk mengukur beban kerja pekerja berdasarkan SNI 7269-2009, maka diperoleh kategori kerja berdasarkan beban kerja. Kategori beban kerja dibagi berdasarkan pengeluaran energi yang terdiri dari beban pekerjaan ringan 100-200 kkal/ jam, beban kerja sedang 200-350 $\mathrm{kkal} / \mathrm{jam}$, dan beban kerja berat 350-500 kkal/ jam. Oleh karena itu dalam penelitian ini dilakukan analisis statistik terhadap variabel yang dianggap saling berhubungan dan berpengaruh, yaitu hubungan variabel independen (usia, masa kerja, beban kerja, dan area kerja) dengan variabel dependen (skor postural/ REBA). Hubungan variabel-variabel ini dalam alat statistik menggunakan probabilitas ( $p$-value). Nilai probabilitas $\mathrm{p}<0,05$ menunjukkan bahwa variabel independen secara signifikan terkait dengan variabel dependen. Semua jenis kegiatan di area produksi dapat dilihat pada Gambar 2 dan 3.

\section{Hasil dan Pembahasan}

Tabel 1 memperlihatkan bahwa pekerja di tiga pabrik karet Kota Padang rata-rata adalah berusia dewasa serta memiliki waktu kerja yang lebih dari sepuluh tahun. Dapat disimpulkan, kondisi ini memudahkan industri karet menimbang usia yang masih produktif serta dengan masa kerja yang cukup, menunjukkan pekerja telah berpengalaman dalam melaksanakan pekerjaannya.

Tabel 1. Karakteristik Responden

\begin{tabular}{llc}
\hline \multicolumn{2}{c}{ Kategori (tahun) } & Persentase (\%) \\
\hline \multirow{2}{*}{ Usia } & Remaja (17-25) & 11,58 \\
& Dewasa (26-45) & 74,74 \\
& Tua (>45) & 13,68 \\
Masa & $<5$ & 21,05 \\
Kerja & & 32,63 \\
& $5-10$ & 46,32 \\
\hline
\end{tabular}

Berdasarkan Gambar 4, menunjukkan frekuensi kategori beban kerja berada pada kategori beban kerja sedang dengan pengeluaran energi 200 $\mathrm{kkal} / \mathrm{jam}-350 \mathrm{kkal} /$ jam sebanyak $86,36 \%$ (area basah) dan $60 \%$ (area kering). Berdasarkan Gambar 5 skor REBA rata-rata area pencucian termasuk dalam level risiko sedang (skor rata-rata 7). Tindakan perbaikannya, pada proses pencucian pekerja melakukan pekerjaannya sambil membungkuk, karena menyesuaikan dengan bak pencucian. Skor REBA ratarata dari area pencampuran adalah dalam level risiko sedang. Pada proses pencampuran pekerja bekerja dalam posisi duduk, sehingga mengurangi postur kerja yang janggal saat bekerja. Skor REBA rata-rata area penggilingan termasuk dalam level risiko sedang. Tindakan perbaikannya diperlukan, pada proses penggilingan pekerja melakukan pekerjaannya sambil membungkuk, karena menyesuaikan dengan mesin gilingan. Skor REBA rata-rata pengeringan alami berada pada level risiko tinggi. Tindakan perbaikannya perlu segera, pada proses pengeringan alami pekerja melakukan pekerjaannya sambil berdiri dan lengan memutar alat pengeringan.

Skor REBA rata-rata pekerja sub area produksi kering dapat dilihat pada Gambar 6. Berdasarkan Gambar 6 skor REBA rata-rata pengawas dan asisten pengawas oven termasuk dalam level risiko sedang, tindakan perbaikannya diperlukan, pengawas dan asisten pengawas oven bertanggungjawab dalam menghidupkan mesin pengeringan (dryer). Skor REBA rata-rata dari area pemotongan karet adalah termasuk dalam level risiko sedang. Pada proses pemotongan karet pekerja bekerja dalam posisi berdiri sambil meneruskan lembaran karet kering ke mesin pemotong karet. Skor REBA rata-rata area pengisian lori termasuk dalam level risiko tinggi. Tindakan perbaikannya perlu segera, pada proses pengisian lori pekerja melakukan pekerjaannya sambil berdiri dan kepala miring ke samping.

Berikutnya, mengacu pada Gambar 6, skor REBA rata-rata bongkar bandela/ peti kemas adalah level risiko sedang. Tindakan perbaikannya diperlukan. Skor REBA rata-rata angkat peti kemas dan penyimpanan termasuk dalam level risiko tinggi, tindakan perbaikannya perlu segera. Pada proses 


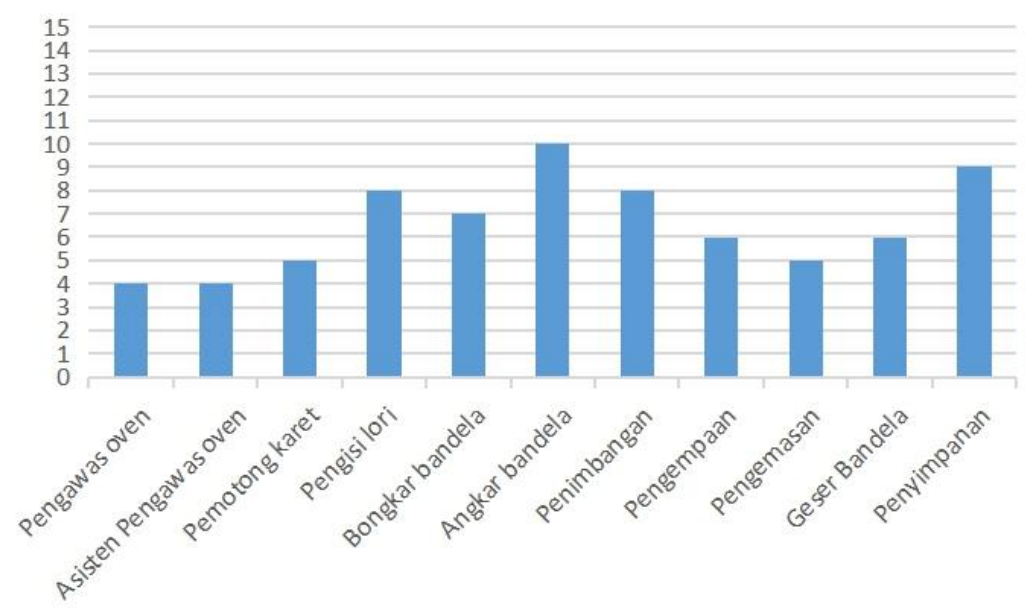

Gambar 6. Skor REBA Rata-rata Pekerja Sub Area Produksi Kering

angkat peti kemas dan penyimpanan pekerja melakukan pekerjaannya sambil berjalan dan peti kemas bertumpu pada leher, sehingga menyebabkan leher tertekuk ke samping.

\section{Hubungan dan Pengaruh Usia terhadap Skor REBA \\ Usia tidak mempengaruhi postur kerja} seseorang, tapi u sia akan mempengaruhi produktivitas seseorang dalam bekerja. Semakin tua seseorang maka produktivitasnya dalam bekerja akan semakin berkurang. Umur seseorang berbanding lurus dengan kapasitas fisik sampai batas tertentu dan mencapai puncaknya pada usia 25 tahun. Pada usia 50-60 tahun kekuatan otot menurun sebesar $25 \%$ serta kemampuan kerja fisik seseorang pada usia lebih dari 60 tahun menurun hingga 50\% dari usia seseorang yang berusia 25 tahun (Swinton dkk., 2017; Ihsan dan Salami, 2020). Dari hasil pengamatan di area produksi tiga industri karet tersebut, terdapat beberapa mesin atau desain tempat kerja yang disesuaikan dengan dimensi tubuh pekerja sehingga saat perhitungan skor REBA nilai yang didapatkan banyak di rentang skor 4-7. Dapat disimpulkan bahwa usia tidak mempengaruhi skor REBA apabila mesin atau desain tempat kerja sudah sesuai dengan dimensi tubuh pekerja.

\section{Hubungan dan Pengaruh Masa Kerja terhadap Skor REBA}

Masa kerja tidak berhubungan dan tidak berpengaruh signifikan terhadap skor REBA. Masa kerja adalah salah satu faktor pada karakteristik tenaga kerja yang mempengaruhi pembentukan prilaku. Semakin lama masa kerja tenaga kerja maka membuat tenaga kerja lebih mengenal tempat kerja dan terbiasa dengan lingkungan kerjanya (Hugo dkk., 2016; Batham dan Yasobant, 2016; Ihsan dkk., 2017).

\section{Hubungan dan Pengaruh Beban Kerja terhadap Skor REBA}

Pekerja dengan beban kerja berat akan mengalami peningkatan kelelahan kerja, hal ini karena pekerja dengan beban kerja berat akan mengeluarkan banyak energi saat bekerja. Beban kerja yang berat akan sangat menguras tenaga apabila pekerjaan tersebut tidak diimbangi dengan waktu untuk beristirahat.

Semakin tinggi beban kerja seseorang maka skor REBA (postur kerja) seseorang akan tinggi juga. Seperti pada proses angkat peti kemas skor REBA yang didapatkan sebesar 9 dan beban kerjanya termasuk dalam kategori berat. Pekerjaan yang terlalu berat dan berlebihan akan mempercepat kontraksi otot tubuh, sehingga dapat menyebabkan seseorang bekerja dengan postur yang salah atau tidak ergonomis. Postur yang tidak ergonomis akan menyebabkan pekerja akan cepat lelah, konsentrasi dan tingkat ketelitiannya menurun, sehingga dapat mengakibatkan terjadinya kecelakaan kerja dan dapat menyebabkan beberapa gangguan otot. Beban kerja yang terlalu berat seperti mengangkat beban dan frekuensi angkat beban dapat mempengaruhi kesehatan pekerja berupa timbulnya nyeri atau cedera punggung (Kalantari dkk., 2016; Polat dan Kalayci, 2016).

\section{Hubungan dan Pengaruh Area Kerja terhadap Skor REBA}

Area produksi basah dan produksi kering memiliki aktivitas pekerjaan dan alat yang digunakan berbeda. Alat ataudesain lingkungan kerja sangat berpengaruh terhadap besar atau kecilnya skor REBA yang didapatkan. Rekapan nilai probabilitas ( $p$-value) dapat dilihat pada Tabel 2.

Tabel 2. Rekapitulasi Nilai Probabilitas Setiap Variabel

\begin{tabular}{lcl}
\hline \multicolumn{1}{c}{ Variabel } & $\boldsymbol{p}$-value & \multicolumn{1}{c}{ Keterangan } \\
\hline Usia & 0,415 & Tidak berpengaruh \\
Massa kerja & 0,952 & Tidak berpengaruh \\
Beban kerja & 0,000 & Berpengaruh signifikan \\
Area kerja & 0,203 & Tidak berpengaruh \\
\hline
\end{tabular}

Berdasarkan Tabel 2 dapat diketahui bahwa dari lima variabel bebas yang dihitung hanya ada satu variabel bebas yang memiliki nilai $\mathrm{p}<0,05$ dan nilai $t_{\text {hitung }}>$ nilai $t_{\text {tabel }}$ yaitu variabel beban kerja. Hal ini menunjukkan bahwa terdapat hubungan dan pengaruh 
Tabel 3. Upaya Perbaikan dan Pengendalian

\begin{tabular}{|c|c|c|}
\hline Area Produksi & $\begin{array}{l}\text { Level } \\
\text { Risiko }\end{array}$ & Solusi \\
\hline \multicolumn{3}{|c|}{ Area produksi basah } \\
\hline Pencucian & Sedang & Meninggikan bak pencuci karet agar sesuai dengan tinggi pekerja \\
\hline Pencampuran & Sedang & $\begin{array}{l}\text { Bekerja dengan menggunakan kursi sandar untuk memperbaiki postur kerja yang agak } \\
\text { membungkuk. }\end{array}$ \\
\hline Penggilingan & Sedang & $\begin{array}{l}\text { Menyediakan meja untuk menampung bandela yang sudah selesai di penggilingan } \\
\text { sebelumnya, sehingga pekerja tidak terlalu membungkuk saat meneruskan bandela ke } \\
\text { mesin penggilingan selanjutnya }\end{array}$ \\
\hline $\begin{array}{l}\text { Pengeringan } \\
\text { alami }\end{array}$ & Tinggi & $\begin{array}{l}\text { Menyesuaikan posisi alat atau mesin dengan dimensi tubuh pekerja sehingga saat bekerja } \\
\text { pekerja tidak terlalu membungkuk }\end{array}$ \\
\hline \multicolumn{3}{|c|}{ Area produksi kering } \\
\hline $\begin{array}{l}\text { Pemotongan } \\
\text { karet }\end{array}$ & Sedang & Pekerja lebih memperhatikan posturnya saat bekerja \\
\hline Pengisi lori & Tinggi & $\begin{array}{l}\text { Memperbaiki cara bekerja pekerja sehingga kepala pekerja saat sedang bekerja tidak } \\
\text { selalu miring ke samping }\end{array}$ \\
\hline Angkat bandela & Tinggi & $\begin{array}{l}\text { Menggunakan alat bantu saat proses pengangkatan atau pengangkutan bandela, sehingga } \\
\text { bendela yang diangkat tidak terlalu berat }\end{array}$ \\
\hline Pengemasan & Sedang & Menyesuaikan tinggi meja dengan tinggi pekerja \\
\hline Geser bandela & Sedang & Menyesuaikan tinggi meja dengan tinggi pekerja \\
\hline Penyimpanan & Tinggi & $\begin{array}{l}\text { Menggunakan alat bantu saat proses pengangkatan atau pengangkutan bandela, sehingga } \\
\text { bendela yang diangkat tidak terlalu berat }\end{array}$ \\
\hline
\end{tabular}

yang signifikan antara beban kerja terhadap skor REBA.

\section{Usulan Upaya Pengendalian Risiko Postur Kerja} Usulan upaya pengendalian postur kerja level risiko sedang sebagai berikut:

1. Memperhatikan jadwal dan rotasi waktu kerja dan waktu istirahat;

2. Mengadakan senam peregangan otot sebelum bekerja untuk menjaga kebugaran tubuh.

Usulan upaya pengendalian postur kerja akibat beban kerja sebagai berikut:

1. Menyesuaikan beban kerja dengan kemampuan tubuh;

2. Melakukan rotasi pekerjaan dan penyesuaian jadwal pekerjaan.

Usulan upaya terkait pengendalian postur kerja yang janggal dapat dilihat pada Tabel 3.

\section{Kesimpulan}

Hasil perhitungan postur kerja pekerja area produksi dengan metode REBA di area produksi termasuk dalam kategori level risiko sedang sebesar $72,34 \%$. Perhitungan skor REBA di area produksi basah yaitu level risiko sedang $(86,36 \%)$ dan pada area produksi kering level risiko sedang $(60,00 \%)$ Skor REBA paling tinggi di area produksi basah yaitu pada proses pengeringan alami, sedangkan di area produksi kering skor REBA paling tinggi yaitu pada proses angkat peti kemas dari lori.

Hubungan dan pengaruh usia, masa kerja, beban kerja dan area kerja terhadap postur kerja di area produksi di Pabrik Pengolahan Karet Padang menunjukkan adanya hubungan dan pengaruh antara beban kerja $(p<0,05)$ terhadap postur kerja pada pekerja area produksi. Selanjutnya tindakan perbaikan postur kerja untuk REBA yaitu dengan cara menyesuaikan posisi alat atau mesin dengan tinggi tubuh pekerja, memperhatikan waktu kerja dan waktu istirahat dan yang paling mendesak adalah dengan cara menggunakan alat bantu saat mengangkat peti kemas.

\section{Daftar Pustaka}

Arminas, A. (2017). Analisis Postur Kerja Aktivitas Pengangkatan Karung di PT. Indofood CBP Sukses Makmur Tbk. Cabang Makassar. J. Optimasi Sist. Ind, 16, 58-67.

Asadi, H., Yu, D., \& Mott, J. H. (2019). Risk factors for musculoskeletal injuries in airline maintenance, repair \& overhaul. Int. J. Ind. Ergon, 70, 107-115.

Batham, C., \& Yasobant, S. A. (2016). Risk Assessment Study on Work-Related Musculoskeletal Disorders Among Dentists in Bhopal, India. Indian J Dent Res, 27,236241.EneZ, K., \& Nalbantoğlu, S. S. (2019). Comparison of ergonomic risk assessment outputs from OWAS and REBA in forestry timber harvesting. Int. J. Ind. Ergon, 70, 51-57.

Chander, D. S., \& Cavatorta, P. M. (2017). An observational method for postural ergonomic risk assessment (PERA). Int. J. Ind. Ergon, 57, $32-41$.

Hugo, A., Rodriguez, F., Viviana, A., \& Mayorga, O. (2016). Characterization of Low Back Pain in Pilots and Maintenance Technicians on a Commercial Airline. Aerospace Medicine and Human Performance, 87,795-799.

Ihsan, T., Edwin, T., \& Irawan, R. O. (2017). Analisis Risiko K3 Dengan Metode HIRARC Pada Area Produksi Pt Cahaya Murni Andalas Permai. 
Jurnal Kesehatan Masyarakat Andalas, 10, 179-185.

Ihsan, T., \& Salami, I. R. S. (2020). Fatigue in Shift Work on Stamping Division Workers of PT. Toyota Motor Manufacturing Indonesia. KEMAS: Jurnal Kesehatan Masyarakat, 15, 316-323.

Joshi, M., \& Deshpande, V. (2019). A systematic review of comparative studies on ergonomic assessment techniques. Int. J. Ind. Ergon, 74, 102865 .

Kalantari, R., Arghami, S., Ahmadi, E., Garosi, E., \& Farahani, A. Z. (2016). Relation Between Workload and Low Back Pain in Assembly Line Workers. Journal of Kerhmanshah University of Medical Science, 20, 26-29.

Kementerian Kesehatan Republik Indonesia. (2019). Profil Kesehatan Nasional 2018. Jakarta: Kementerian Kesehatan.

Kong, Y.G., Lee, S., Lee, K. S., \& Kim, D. M. (2017). Comparisons of ergonomic evaluation tools (ALLA, RULA, REBA and OWAS) for farm work. Int. J. Occup. Saf. Ergon, 24 (2), 218-223.
Polat, O., \& Kalayci, C. B. (2016). Ergonomic Risk Assessment Of Workers In Garment Industry," in Textile Science and Economy: Proc of The 8th International Scientific-Professional Conference (pp. 124-129) May 16-19, 2016.

Schwartz, A. H., Albin, T. J., \& Gerberich, S. G. (2019). Intra-rater and inter-rater reliability of the rapid entire body assessment (REBA) tool. Int. J. Ind. Ergon, 71, 111-116.

Sukadarin, E.H., Deros, B.M., Ghani, J., Mohd-Nawi, N.S., \& Ismail, A. R. (2016). Postural assessment in pen-and-paper-based observational methods and their associated health effects: a review. Int. J. Occup. Saf. Ergon, 22(3), 389-398.

Swinton, P. A., Cooper, K., \& Hancock, E. (2017). Workplace interventions to improve sitting posture: A systematic review. Preventive Medicine, 101, 204-212.

Wahyuniardi, R., \& Reyhanandar, D. (2018). Penilaian Postur Operator dan Perbaikan Sistem Kerja dengan Metode RULA dan REBA (Studi Kasus). J@ti Undip: Jurnal Teknik Industri, 13, 45-50. 